Acta Horticulturae et Regiotecturae 2

Nitra, Slovaca Universitas Agriculturae Nitriae, 2020, pp. 71-75

\title{
RECOGNISING GREEN INFRASTRUCTURE AS A PART OF THE FOURTH NATURE CONCEPT THROUGH UNIVERSITY CAMPUSES
}

\author{
Miroslav ČIBIK ${ }^{1,3}$, Simone BACK PROCHNOW ${ }^{2,3}$, Richard STILES ${ }^{3 *}$, Roberta ŠTĚPÁNKOVÁ ${ }^{1}$ \\ ${ }^{1}$ Slovak University of Agriculture in Nitra, Slovakia \\ ${ }^{2}$ Federal University of Rio Grande do Sul in Porto Alegre, Brazil \\ ${ }^{3}$ Vienna University of Technology, Austria
}

\begin{abstract}
Every ecosystem on Earth is affected by people as well as has an impact on them. The connection between nature and culture, human knowledge and wisdom of Nature, between us and our environment, is in fact very strong, although sometimes underestimated. It can be promoted by a different way of designing architecture and urban plans - these all should change the quality of our decisions and consequently, once we are acquainted with better options or choices to select, also the quality of our lives will be raised. The Fourth Nature concept is being researched with the goal to identify strategies that create straight connections between culture and Nature, in order to provide humanity with better conditions for living in cities. We are urban beings, living with a current prognosis of being a part of a bigger number of urban dwellers each day. Many different ways the Fourth Nature can be practiced, seen and experienced by in several scales and forms could change our living conglomerates. As valuable places in cities, due to their insertion in the urban tissue and also as coexistence and knowledge development areas, university campuses are here taken to examine this aimed optimal relation between Nature and culture. University campuses have been for centuries an important part of human culture. Creating their own ecosystems, campuses impact on the functioning, sustainability and in the overall also on the appearance of the city, through a blue-green infrastructure implementation and its connections. Within the urban structures, they fulfil their role more significantly and provide important spatial, social, economic, visual and health functions. The area, which is often labelled as public or semi-public space, is thus a part of the blue-green infrastructure and its quality affects also the quality of the surrounding environment. The Fourth Nature is seen as a tool or as a turning point in the current environmental crisis and the university campuses are considered to be the modifiers of the quality of their surrounding environment. The intercrossed analysis of their properties in the current context may bring new ideas and application parameters for the design of the contemporary urban landscape.
\end{abstract}

Keywords: the fourth nature, a blue-green infrastructure, ecosystem services, urban structures

The population growth, constant and continuous movement of everything around us, social, cultural and technological changes (Hashimshony and Haina, 2006) and urbanization affect the development of urban structures towards suburbs. Automobiles are becoming an essential type of transportation in the $21^{\text {st }}$ century, leading to an increase energy consumption, air pollution, time-consuming, traffic congestion, diseases, dysfunction society and etc. (Rashidi, 2013). The importance of green elements in the densely populated cities and in its developing areas is derived from the attempt to stop the climate change and improve infrastructure, until we modify our well-being status. The study of the Fourth Nature concept deals with all these spheres, since it involves the relation man-nature in time and tries to foresee which way we could go to change our near future (Prochnow and Abreu Filho, 2018). Today, in a busy period and a continual movement of everything around us, the character of the living areas is dynamically changing in a connection with an alternation of mode, art or even opinions. The ambit of changes is seen mainly in the alterations of a functional application of architectural objects and their premises (Čibik et al., 2019). These movements show that we, human beings, are in a continuous evolution and solutions, which fulfil our most updated needs, of both physical and mental health, must with no doubt embrace Nature, as it has been already explored by many authors. As the number of people living in our garden planet approaches seven billion, with a probability to reach nine billion by the middle of the century, the possibility of sustaining a harmonious life in Nature seems even more remote, as Giesek and Jacobs (2012) said in Earth Perfect. The alterations are grand. Today, our urban lives depend most fundamentally on global ecologies and the political economies, which uphold them (Keil, 2003). Architecture and urban design have a main responsibility in this process: the application of ecological approaches in landscape is one of the main steps in creating urban areas without an environmental deterioration and increased financial demands caused by necessary maintenance and sociological effects on new generation (Vaculová and Štěpánková, 2017).

Contact address: Ing. Miroslav Čibik, Slovak University of Agriculture in Nitra, Faculty of Horticulture and Landscape Engineering, Department of Garden and Landscape Architecture, Tulipánová 7, 94976 Nitra, Slovakia; J +421 9488494 90; e-mail: cibik.miro.o@gmail.com 


\section{Theoretical background}

The Fourth Nature concept is being defined in research that aims to recognise a new perspective in the relationship man-nature. An updated concept, which takes our consciousness and responsibilities as perceptual subjects into consideration, both influences the perceived object and is influenced by it. Experiencing Nature means to be an observer and a part of it, at the same time. It is with no doubt a two-way path. To consolidate this comprehension, important ideas were found throughout the history, for example, the 'Second Nature' concept, written by Cicero in his book De natura Deorum (41 BC). He already defined the Second Nature as the nature modified by man to serve his purposes and satisfy his basic needs such as food and transport. Hunt (1992) believes, that Cicero's concept would be known by the Italians in the Renaissance, since in 1541, Jacopo Bonfadio wrote about gardens that started to be constructed in a refined way, never seen before. These amazing landscape designs were proposed by other authors, too (such as Bartolomeu Taegio) to be the 'Third Nature' - una Terza Natura - gardens as 'Nature incorporated to artwork'. The main resources of human intelligence and technological skills were invoked to bring these astonishing results, as the search of pleasure from contemplation would overcome the utility purposes. Even though Cicero is not explicit, his words imply the existence of the First Nature, the pristine Nature, untouched by humans. The First Nature would be the kingdom of Gods and also the raw material for the Second Nature (Hunt, 1992).

The important point to consider is that the primitive Nature has been constantly processed for the human consumption and transformed either into the second and then into the third Nature or sometimes directly into the third Nature. This consumption involves the search of conditions for housing, agriculture, transportation, religious beliefs and eventually, leisure or aesthetic pleasure. Whatever the purpose is, the redoing of the primitive Nature makes the physical world milder, more useful, tolerable, pleasant and beautiful, as Hunt describes. The specific emphasis depends on which historical moment the transformation has been set on, together with the place and the social-economic situation. Today's adjectives would also include 'ignored' and 'destroyed', if we look at the majority of our cities. When we realise, in which 'historical moment' we are living now, it is preponderant to perceive that today, we need far more than just a food-transport-contemplation. It is based on our awareness of the importance of designing our places integrated and with a respect for Nature, sine qua non condition for our survival would exist. It is the meaning that the Nature brings to our lives, which enhances its importance.

One of the great myths of our time is about the particular relationship with nature, which we observe within the confined realm of our cities (Girot in Becker and Cachola-Schmal, 2010).

As we will live more and more in cities and cities cause the biggest problems concerning environment, the Fourth Nature concept is focused right on the big cities. However, it is also relevant to see the city not as a problem, but accept it as the solution for our future - this brings a more productive way of thinking. Adli (2017) in his work Stress and the City deals with the question: why do cities make us sick and why are they still good for us? What a great question. The Fourth Nature concept considers that what we need today is to create a dynamic interface between the natural and cultural, in which we will use all the available technology and also takes our real dependence on the natural resources and its benefits into consideration.

It is also a way of sensitising us by reintroducing, enhancing and prioritizing Nature within the cities, so that we reconnect with its cycles and rhythms and live healthier. The main factor of the Fourth Nature may be that it combines a whole spectrum of experiences offered by the presence of Nature in the city with different dimensions of our connection to it, of our perception or awareness by satisfying our body and mind needs. There are many ways, scales, and possibilities of such aim implemented, one of them being the blue-green infrastructure (Prochnow, 2019).

The blue-green infrastructure refers to a network of green building strategies within the cities that connect the existing green features with each other and with the wider landscape that surrounds it (Benedict and McMahon, 2006). University campuses are places where these connections occur strongly, once they become a designed area with open spaces, within or in the borders of the cities and thus, provide an added value to it. This is how this crossed analysis proposal is validated, especially nowadays, when another way of planning comes up by reversing the usual actions as ignoring or destroying into a conscious designing. These consider the importance of an holistic approach for urbanism and architecture, in which Nature is one of the main items in the projects, while not considering the open spaces being the 'unused areas'. Moreover, they are perceived as the most valuable ones and the blue-green infrastructure features as elements, which enhance local characteristics, multiple benefits, less maintenance in a long term view and above all the ones, which connect sites and people.

\section{Material and method}

Green infrastructure, as a part of the Fourth Nature concept, is globally considered to be the most effective strategic planning tool to help create a sustainable and resilient urban landscape. It is also an effective measure to mitigate the effects of the climate change, providing a range of ecosystem services as well as social, environmental and economic benefits (Tóth and Feriancová, 2015; Mell, 2016). The university campus is a part of these structures and through the hierarchy of the individual buildings, the campus creates inter-pavilion spaces with a public character, which, in terms of quality and overall visual identity, affect the surrounding environment equally significantly (Čibik and Štěpánková, 2019).

\section{Results and discussion}

As a part of the European Concept of the university campuses, university campuses were designed near the city structures in the 1960s and 1980s, and their immediate surroundings became dense as they got gradually urbanised 


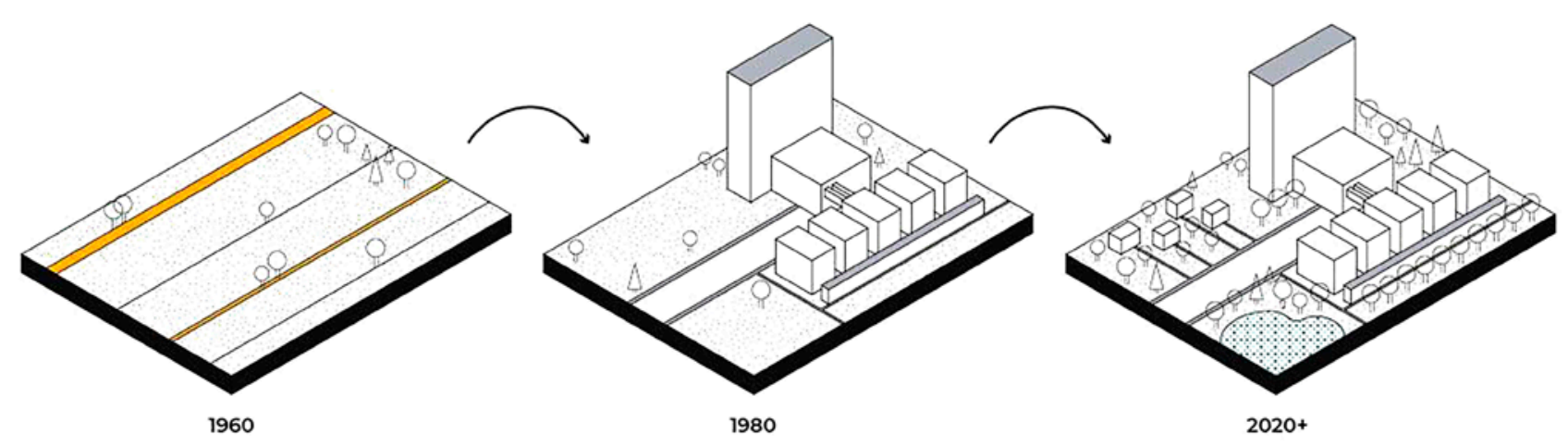

Figure 1 University campuses development. Some university campuses, mostly designed within the European concept and originally designed on the outskirts of cities, are becoming a part of the urban space, due to a massive urbanisation. City campuses are gradually taking up the function of open spaces and their environment significantly influences the surroundings

(Fig. 1). Today, they form important buildings and areas in the city centres and significantly influence their operation. In its in between spaces and buildings (physical matters), as well as by its character (of the intellectual growth of the place, where the new ideas are being developed) and by its constant renewal processes, campuses represent an interesting place to observe and implement the Fourth Nature possibilities - as a blue-green infrastructure. From the big spatial green features as are tree groups and grass relaxing areas, to the most developed strategies of roof and wall greening, different scales of green and water utilization can trigger an effect of interest as well as a result of wellbeing in its users and visitors. The full interaction among the users, natural/built green backgrounds and the natural phenomena brings the utmost results.

This is why the conceptual thinking within the green infrastructure tools is indispensable not only for the design of the environment, but also for the understanding of the future opportunities and threats. In this aspect - perhaps more than in the past - the process of creation has become a process of identification and exploration, a process of creativity for exploring new spatial possibilities and new methodological approaches.
According to the consequence of suburbanization, the architectural community seeks a solution to reduce the negative effects of a massive urbanization on the culture and economy of the cities and an aim to achieve a sustainable city (Rashidi, 2013). The sustainability of a university campus (Reid, 2008) can be increased through the bluegreen infrastructure strategies, once it changes not only its environmental processes but also once it promotes its connection to the city's metabolism as a whole-byimproving it. However, regarding to Melková (2014), only an accessible area is justified in the city, as long as it compositionally and urbanistically corresponds to the structure of the city and contributes to its (cultural) enrichment. The well-being of users and social living conditions are therefore the results of the blue-green infrastructure and also serve as an important place-making strategy, since creating high quality open spaces should focus not only on students but also on every citizen. The title 'University Campus' expresses who the space is intended for. People perceive the premises of the campus, but they often have inhibitions to spend time in it. They think that the campus is private, that it belongs to the university and not to everyone and they have respect to the area. The boundaries of the campus must be clearly defined but it is better, when the edges are made up by buildings

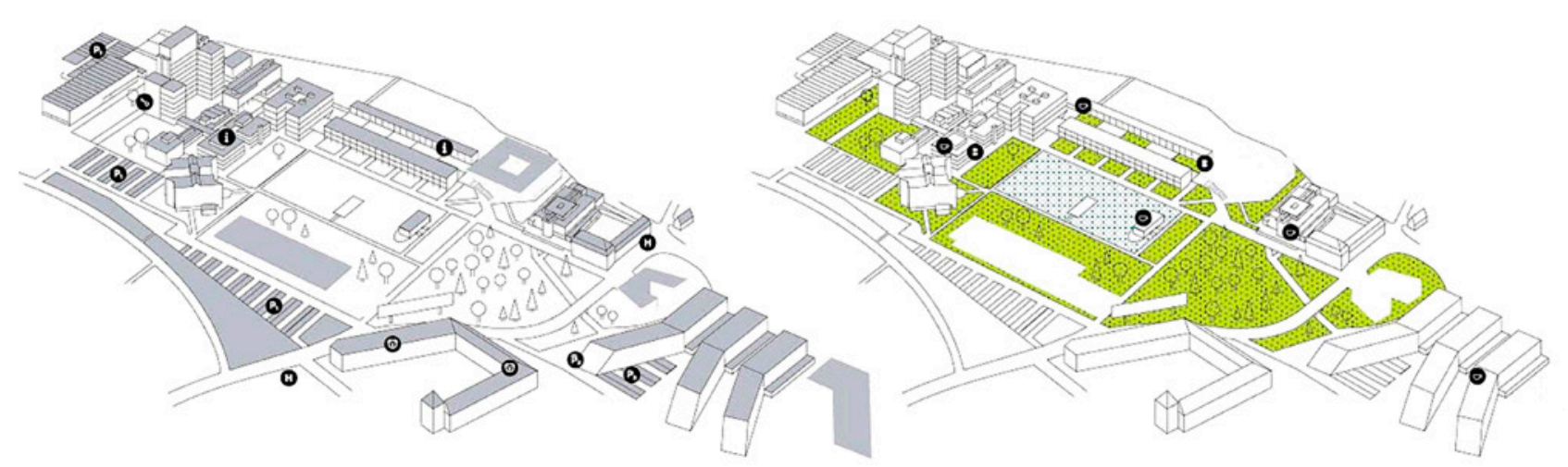

Figure 2 Representation of green spaces, open spaces and community-based services compared to buildings, car parks or areas not accessible to the public. The positive example of JKU - Johanes Kepler University campus in Linz (Austria) Source: JKU and vectorised by Čibik and Štepánková (2019) 
and open spaces than by walls or fencing. Concerning the character of the surrounding development, there are discussions about the semi-public, semi-private or even private space, but the collective space is always the result, which should guarantee comfortable usage for all groups of population, regardless age, social and cultural background and handicap. Green infrastructure tools are one of the many ways for ensuring such aim. Campuses are open and connected with surroundings and not just specific and complementary types of the public spaces. They also offer their territories to everyone, although at a different level. As Rawn (2002) describes, open spaces positively influence the relationships with the city, which include landscape, pavements and urban furniture. The size and number of floors of the individual objects (buildings) of the complex must respect the panorama of the city and their number should correspond with the number of trees and other vegetation (greenery). In order to develop 'city - university campus' relations, the ratio between the greenery and the open spaces within the campus must be roughly equal or even greater than exactly the same ratio, but within the city (Fig. 2).

When talking about the public space quality, it becomes intrinsic to value green spaces and its multidimensional possibilities, in order to enhance cities life quality. According to The United Nations, the world population living in the urban area in 2011 reaches 52.1\% (United Nations, 2011). The development of urbanization has therefore big effects on the way people live, related to the natural, physical, social, cultural and economic dimensions. This makes the gaining sustainability an essential authoritative condition to the urban areas (Jenks and Dempsey, 2005). Providing a direct contact with Nature in a reasonable walking distance for every citizen is a basis in visionary urbanism. University Campus can be a provider of green areas in the city. And as these green features offer not only contemplation but also systematic services, they become extremely efficient and thus, the Fourth Nature, green infrastructure and campuses interrelate.

Higher education and more job opportunities in the labour market attract young people to study at universities. University campuses were established as a result of gradually expanding universities. The influx of new students was so great that the individual capacities of the universities were not enough. Today, the university campus is one of the main elements of the city and significantly affects the sustainability of the city and the surrounding environment. Therefore, it is important that there are physical, economic and socio-cultural relationships between the city and the university campus. The university campus positively affects the development of the city and its interconnection with the urban structures and also increases the social activities that lead to the development of the economy and the integration of students with the local inhabitants. According this, the campus affects the city. If the campus becomes sustainable, the city can also become. In these terms, a sustainable campus can be considered one of main concepts of growing sustainability in the cities. In other words, the city can improve its sustainability when having the university campus well located, accessible and planned in sustainable forms. Moreover, for achieving a sustainable university campus, main dimensions of a sustainable university as are natural environment (Melo et al., 2020), social, cultural and economic ones must be considered in the university strategy plan (Lukman and Glavic, 2007). Cultivated squatted urban and peri-urban areas, which undoubtedly the university campuses could be considered as, represent a significant element of the Urban Agriculture (UA) (Tóth and Feriancová, 2015), which, according to Lohrberg (2011) and Lohrberg and Timpe (2012), provides an important contribution to a sustainable and resilient urban development and creation and maintenance of the multifunctional urban landscapes. The UA has been increasingly recognised for the multiple functions, which are supported by it and which the urban society benefits from (Bryant, 2012). Moreover, the university campuses are considered to be large scale green areas in the city borders, too.

Thus, the urban planning is a complex task, which requires multidimensional urban information (spatial, social, economic, etc.) (Kliment et al., 2015). There are some basic standards in the design process, which define the relationship between the user and the university campus at different levels. Surrounding space, dynamic and static motion, safety, visual identity, permeability and etc. are some of these standards. Successful design of the university campus is achieved through a balance between these standards and achievement of the successful urban space, which suits the purpose for which it is established, while meeting the users' needs. Thus, a responsive urban design of the environment and the utilization of this space by humans are both achieved (Rached and Elsharkawy, 2012).

\section{Conclusion}

We can consider that the usage of the blue-green infrastructure strategies, as part of the Fourth Nature concept, is a very useful tool towards the achievement of this complex task, once it can embrace several of the desired targets. The campus vegetation for example, meets an important role in the cultural, educational and historical rescue, as well as in the transition from the natural to the built environment. The green areas and their usage as an urban park strengthen the valorisation of the campus. Through the education and research, it is possible to integrate an active learning with a social responsibility and environment by encouraging the construction of sustainable paths, improving the users' contact with Nature, as well as by directing the development of the design towards sustainability and consequently, towards a healthier life, in which people are more conscious of the need of interacting with Nature - as the Fourth Nature concept proposes. Our vision of the future may change our actions in the present. Today's generation is influenced and encouraged by new experiences. Living in an interesting environment, which is also effective in solving structural systems as well as it is a dynamic, livable, multipurposeful and attractive place, is the perspective we are looking for. University campuses can become such desired places within the cities, once we recognise them as innovative and learning places, where the blue-green infrastructure strategies are planned, and the Fourth Nature concept is materialised, and once they reconnect us with the environment and make us perceive, 
enjoy and take benefits from the presence of Nature in our daily life routine - in a virtuous cycle.

\section{Acknowledgement}

The paper is an outcome of national educational and scientific projects of the Ministry of Education, Science, Research and Sport of the Slovak Republic VEGA 1/0371/18, research project KEGA 003SPU-4/2020 and research project KEGA015SPU-4/2020 (UNI-ARCH). The authors would like to express special thanks to VEGA 1/0371/18, KEGA 003SPU$4 / 2020$ and KEGA 015SPU-4/2020 for covering all the expenses.

\section{References}

ADLI, M. 2017. Stress and the City. München: Bertelsmann Verlag, 384 p. ISBN 978-3570102701

BENDEDICT, A.-McMAHON, E. 2006. Green Infrastructure Linking Landscapes and Community. London: London: Island Press, 320 p. ISBN 978-1597267649.

BRYANT, R. C. 2012. Keynotes: The discovery of Urban Agriculture. In COST Action Urban Agriculture Europe: Documentation of $1^{\text {st }}$ Working Group Meeting. Aachen: COST, ESF, RWTH Aachen University, 2012. pp. 5-9.

ČIBIK, M. - ŠTĚPÁNKOVÁ, R. 2019. A Multi-Criteria Assessment of the Open University Campus. In Veda mladých 2019 - Science of Youth 2019. Nitra : SUA, 2019, pp. 33-44. ISBN ISBN 978-80-552-2008-6.

ČIBIK, M. et al. 2019. Integration of the Historical Watermill into a Sustainable Peri-Urban Riverfront Redesign. In Public recreation and landscape protection - with nature hand in hand. Brno: MUAF, 2019, pp. 212-216. ISBN 978-80-7509-659-3.

GIESECKE, A. - JACOBS, N. 2012. Earth Perfect? Nature, Utopia and the Garden. London : Black Dog Publishing Limited, 2012, 306 p. ISBN 978-1907317750.

GIROT, C. 2010. Naturerfahrung und Symbolik im Stadtgrün In BECKER, A. - CACHOLA - SCHMAL, P. Stadgrün/Urban Green. Europa Landscape Design for the $21^{\text {st }}$ Century/Europäische Landsschaftsarchitektur für das 21. Jahrhundert. Birkhäuser Verlag GmbH, Basel, 2010, pp. 218-225. ISBN 978-3-0346-0313-3.

GIROT, Ch. 2005. Vers Une Novelle Nature. In ADAM, H. - DETTMAR, J. - GIROT, Ch. - HAUSER, S. - KOCH, M. - KOHTE, M. - MEILI, M. PICON, A. - ROTZLER, S. - WALDHEIM, Ch. Landscape Architecture in Mutation - Essays on Urban Landscape. GTA Verlag, Zürich, 2005. HUNT, J. D. 1992. Gardens and the Picturesque - Studies in the History of Landscape Architecture. Cambridge: MIT Press, 408 p. ISBN 978-0262581318.

JENKS, M. - DEMPSEY, N. 2005. Future forms and design for sustainable cities. [online]. Oxford : Architectural Press [cit. 202003-05], pp. 1. Available online: https://www.uop.edu. jo/download/ research/members/\%5BArchitecture Ebook\%5D Future_Forms and Design for Sustainable Cities.pdf

JKU LINZ : axonometry of the campus. 2019. JKU - ein Campus blüht auf! [online]. Linz : JKU Linz [cit. 2020-03-05].Available online: https://www.jku.at/campus/der-jku-campus/campusentwicklung/ KEIL, R. 2003. Urban Political Ecology. In Urban Geography Journal, vol. 24, 2003, no. 8, pp. 723-738.
KLIMENT, M. et al. 2015. Land Use Dataset Collection And Publication Based On Lucas And Hilucs. In Acta Horticulturae et Regiotecturae, vol. 17, 2015, no. 2, pp. 52-59.

LOHRBERG, F. - TIMPE, A. 2012. COST Action Urban Agriculture Europe: Documentation $1^{\text {st }}$ Working Group Meeting. Aachen : RWTH Aachen University, 2012, 98 p.

LOHRBERG, F. 2011. Urban agriculture - General aspects and examples from Germany. In Scales of Nature: $48^{\text {th }}$ IFLA World Congress Proceedings. Zürich : IFLA, BSLA, 2011, 148 p.

LUKMAN, R. - GLAVIC, P. 2007. What are the key elements of a sustainable university? In Clean Techn Environ Policy [online]. [cit. 2020-03-05], 2007, pp. 104-106. Available online: DOI: 10.1007/ s10098-006 0070-7

MELKOVÁ, P. 2014. Manuál tvorby veřejných prostranství hlavního města Prahy. Praha : IPR/SDM/KVP, 2014, 290 p. ISBN 978-80-87931-11-0.

MELL, I. 2016. Global Green Infrastructure: Lessons for Successful Policy-Making, Investment and Management. Oxon, New York : Routledge, 2016, 212 p. ISBN 978-1-138-85464-2.

MELO, E. F. R. Q. et al. 2020. Recognizing Sustainability in a University Campus Through a Green Trail. In Universities and Sustainable Communities:Meeting the Goals of the Agenda 2030, [online]. [cit. 2020-03-05]. 2020, pp. 2-11. Available online: http:// doi.org/10.1007/978-3-030-30306-8_46

PROCHNOW, S. B. - ABREU FILHO, S. B. 2018. QuartaNatureza, Uma Nova Pauta no Projeto de Arquitetura e Urbanismo. In V ENANPARQ Encontro da Associacao Nacional Arquitetura e Urbanismo. [online]. [cit. 2020-03-05]. Available online: https://repositorio.ufba. br/ri/handle/ri/2744

PROCHNOW, S. B. 2019. Fourth Nature: Healing Places. In Kultur Revista Interdisciplinária Sobre la Cultura de la Ciutat. Valencia, Spain, vol. 6, 2019, no. 12, pp. 203-224. ISSN 2386-5458.

RACHED, I. - ELSHARKAWY, H. 2012. The Role of Open Spaces in the University Campus in the Egyptian context. In Designing Place International Urban Design Conference. Nottingham : University of Nottingham, 2012, pp. 1-15.

RASHIDI, A. 2013. University Campus as a Public Space of the City - Case Study: Eastern Mediterranean University Campus : doctoral dissertation thesis. Gazimağusa, North Cyprus : Eastern Mediterranean University, 2013, 201 p.

RAWN, W. 2002. Campus and the city. In Rawnarch [online]. [cit. 2020-03-05], 2002, pp. 1-6. Available online: http://www.rawnarch. com/pdf/CampusandtheCity.pdf

REID, R. C. 2008. Using LEED as a resource for campus sustainability planning: a white paper: doctoral dissertation thesis. Berkeley, United States : University of California, 2008, $184 \mathrm{p}$.

TÓTH, A. - FERIANCOVÁ, L.. 2015. Landscape As A Resource For Squat Farming. In Acta Horticulturae et Regiotecturae, vol. 17, 2015, no. 2, pp. 35-37.

UNITED NATIONS. 2011. World Urbanization prospects: the 2011 revision. [online]. [cit. 2020-03-05]. Available online: http://www. esa.un.org/unup/CD-ROM/Urban-Rural-Popula-tion.htm

VACULOVÁ, V. - ŠTĚPÁNKOVÁ, R. 2017. Application of Rain Gardens to an Urban Area - Housing Estate in Nitra, Slovakia. In Acta Horticulturae et Regiotecturae, vol. 20, 2017, no. 1, pp. 1-5. 